\title{
The Religion of the Kara Koyunlu Dynasty: An Analysis
}

\author{
Seyyed Masoud Shahmoradi ${ }^{1}$, Mostafa Pir Moradian $^{1} \&$ Asghar Montazerolghaem ${ }^{1}$ \\ ${ }^{1}$ History Department, University of Isfahan, Isfahan, Iran \\ Correspondence: Seyyed Masoud Shahmoradi, History Department, University of Isfahan, Hezar Jareb Street, \\ Isfahan, Iran. Tel: 98-914-623-8864. E-mail: shahmoradi86@yahoo.com
}

Received: January 3, 2013 Accepted: January 27, 2013 Online Published: March 22, 2013

doi:10.5539/ach.v5n2p95 URL: http://dx.doi.org/10.5539/ach.v5n2p95

\begin{abstract}
Different scholars have considered the Kara Koyunlu "Twelver Shiites", "Radical Shiites" and some others "Sunnites." A review of the "criteria for being recognized a Shiite" and comparing them with the Kara Koyunlu can confirm that they were Shiites. However, the Kara Koyunlu must be considered as having a type of Shia referred to as doctrinal Shia and Sufic Shia which having been formed through Shi'ization of the Sunnites and sharing Sufic characteristics, does not belong to any of the common sects of Shia. The present study aims to prove that the Kara Koyunlu were Shiites using descriptive-analytic method and library research.
\end{abstract}

Keywords: The Kara Koyunlu, Persia (Iran), Azerbaijan, Shia, Sunni, Sufism

\section{Introduction}

The religious beliefs of the Kara Koyunlu as a Persian ruling dynasty are important and interesting aspects and different, sometimes even contradictory opinions have been expressed about them. Various old and contemporary sources have referred to the Kara Koyunlu as followers of Twelver Shia, Exaggerating Shia, and sometimes Sunni. A review of the criteria for being recognized a Shiite and the religious transformations in Iran after the Mongol invasion of Persia can help us substantiate whether or not the Kara Koyunlu were Shiites, determine the Shia sect they belonged to and thereby pinpoint the reasons for scholars' various opinions on the matter of the Kara Koyunlu's religion. Several Shia history scholars have specified some criteria for the Shia of some people and families by comparing of which to this dynasty we may arrive at a general verdict about the Kara Koyunlu' faith. After the Mongol invasion of Persia due to the political schism in the country and the Mongols' religious tolerance which led to the demise of the Sunni rule, the Shiites found the opportunity to participate in intellectual and political activities. On the o the other hand, Mongol conquest of Persia caused a general tendency among the public toward Sufism. This phenomenon was the direct result of Mongol tyranny and tremendous pressure on Iranians and their incapability to confront it. In this era, Sufism had become an intermediary between Shia and Sunni and paved the way for the expansion of Shia. It was through this process that many converted to Shia by Sufic ways. Another factor which facilitated this trend was the role of the Shafi'i faith and its similarity to Shia. Taking into consideration the above factors, we find a type of Shia referred to as Doctrinal or Sufic Shia which has come into existence through a process called Shi'ization of the Sunni. While presenting a review of the religious conditions of Persian during the period after the Mongol invasion, the present study attempts to answer the following questions: what are the criteria for calling a certain ruling person or family Shiite and what result would be obtained if the Kara Koyunlu matched these criteria? In case it is proved that the Kara Koyunlu were Shiites, what Shia sect they belonged to? In addition to the two aforementioned questions, this question will also be answered: what is the reason for scholars' various and contradictory opinions about the Kara Koyunlu's type of religion?

\subsection{The Origin and Political History of the Kara Koyunlu}

The Kara Koyunlu were one of the twenty four Oghuz Turks or referred to in Islamic sources as Turkmen who, during the Mongol domination at the time of Arghun of the Ilkhanate dynasty, moved from the Turkestan area westward and settled down in Azerbaijan, then Arzinjan and Sivas (Mir Ja'fari, 1384, pp. 227-228). The Turkic term kara koyunlu means black sheep or black sheep owners. Regarding the reasons for this designation, the image of a black sheep on their flags, their sheep's breed, their possessing great number of sheep are mentioned among other reasons. In historical sources, the Kara Koyunlu have also been designated as barani, baranlu, and baranli. It is highly probable that Baran might have been the place this tribe belonged to (Mir Ja'fari, 1384, pp. 226-227). Sultan Kara Muhammad (1380-1390 C.E) was the first powerful man among the Kara Koyunlu, who 
had great influence on the events of Eastern Anatolia, Persia, Syria and some parts of Iraq because of his active personality and the geographic situation of the time of his ruling; he also successfully defended his territory against the invasion of Timur (Mir Ja'fari, 1384, p. 235). The greatest ruler of this dynasty was Kara Yusuf (1380-1402 C.E) who rose up against Timur and following Timur's second invasion of Persia, fled to the Ottoman Bayezid and then sought refuge in the Mamluks (Ibn-e Arabshah, 1356, p. 173). He returned to Tabriz after Timur's death in 1406 C.E and ended the Jalayirid domination of Azerbaijan and Iraq (Vale Esfahani, 1381, pp. 680-705). In fact, the Kara Koyunlu government was established at this time (Mir Ja'fari, 1384, p. 240). Timurid Shahrukh (1404-1447 C.E), who did not want to leave Azerbaijan in the hands of Kara Yusuf, launched three campaigns on Azerbaijan to confront him. Kara Yusuf died in 1420 C.E while preparing to battle with Shahrukh (Samarkandi, 1353, p. 412) and Azerbaijan fell to Shahrukh (Tehrani, 1356, pp. 73-74). Kara Yusuf is considered the actual founder of the Kara Koyunlu Dynasty and its greatest leader. Eventually, Shahrukh gave Azerbaijan's rule to Kara Jahan Shah (1433-1467 C.E), Yusuf's son (Tehrani, 1356, pp. 138-139). Since the powerful Timurid Shahrukh died, Kara Koyunlu Jahan Shah expanded his ruling territory to Iraq, Fars, Kerman and even Oman and turned the Kara Koyunlu Turks into a world power (Bosworth, 1381, p. 522). Jahan Shah, who was establishing a powerful, expansive government in Western Persian and had won almost all the battles against his adversaries, was defeated and killed by Uzun Hassan (1457-1477 C.E), the Ak Koyunlu Dynasty ruler (Tehrani, 1356, pp. 424-430; Ghiasi, 1975, pp. 293-299), and thus the vast Kara Koyunlu empire was disintegrated (Hinz,1362, p. 61). Jahan Shah is doubtlessly considered the most powerful Kara Koyunlu leader. After Jahan Shah's death, his son Hassan Ali enjoyed a brief period of domination, but was finally killed by Okurlu, Uzun Hassan's son. Jahan Shah's brother, Abu Yusuf Mirza was also killed by Okurlu Muhammad. With the death of the Jahan Shah's last sons, the Kara Koyunlu resistance was finally broken and Azerbaijan fell into Uzun Hassan's hands (Tehrani, 1356, pp. 507-510; Ghiasi, 1975, pp. 41; 331). The Kara Koyunlu rulers reigned over Iraq and Azerbaijan for one hundred years. Some of these rulers reigned over both Iraq and Azerbaijan and sometimes one reigned over Azerbaijan and another over Iraq.

\subsection{The Religion of the Kara Koyunlu}

One interesting point of analysis regarding the social life of the Kara Koyunlu is their religious status for there are many different opinions about religious beliefs of the Kara Koyunlu. Some scholars believe the Kara Koyunlu to be followers of Twelver Shia; some others consider them Radical Exaggerating Shiites and others Sunnites (Hassanzadeh, 1386, p. 49). What is noteworthy concerning the religion of the Kara Koyunlu is that different scholars have arguably ascribed to the Kara Koyunlu a range of religions from Exaggerating Shia and Twelver Shia to Sunni. Therefore, the best way to determine their religion would be identifying the criteria needed to be met by people and families to be "qualified as Shiites" and a applying them to the Kara Koyunlu and thus determine the religion of this ruling family.

The Criteria for being recognized a Shiite

Some Shia historiographers have delineated some criteria for Shia. These criteria include:

1. An author or historian's explicit emphasis on the person being a Shiite (considering on what grounds and which author has ascribed Shia to that certain person);

2. The person's connection with a city whose people have been unanimously Shiites;

3. Burial in the vicinity of one of the Shia Holy Shrines

4. The explicit admission of the person himself to being a Shiite in a statement (or an incident);

5. Being an Alavid;

6. Imprinting the chant "Ali Vali-ullah" on coins;

7. Having been taught by a Shiite instructor or a book showing his Shia or of Shiite father;

8. Familial connection with or personal attachment to a Shia family (Ja'fari, 1388, pp. 77-87); and

9. Architectural and archeological remnants indicating Shia signs.

By comparing one or a number of the mentioned criteria to the Kara Koyunlu, we may form a more definitive judgment about this family's type of Shia.

\subsection{The Criteria for Being Recognized a Shiite and Shia Signs in the Kara Koyunlu}

\subsubsection{An Author or Historian'S Explicit Reference to the Shiism of the Person or Family}

In determining one person's Shiism, the first criterion is a historian's explicit reference to that certain person's Shiism (Ja'farian, 1388, p. 79). In this regard, numerous narratives by the historians can be found in which they refer to the Kara Koyunlu as Shiites. Historians' narratives about the Kara Koyunlu's Shiism can be divided into 
two types: narratives in which they refer directly and explicitly to the Kara Koyunlu's Shiism and narratives in which they show it indirectly by making references implying the Kara Koyunlu's Shiism. Concerning the latter type of narrative, we should mention the narrative discourse of some reports in the historical sources of the Sunnites because several Sunnite writers have reported some facts about the Kara Koyunlu and its leaders. Even though these writers do not mentions the Shia faith of the Kara Koyunlu, if we consider the Sunnite narrative sources on the Shiites, in particular Shiite rulers, we may arrive at a verdict about the Kara Koyunlu's Shiism based on those sources.

(a) Narratives explicitly mentioning the Kara Koyunlu's Shiism:

In his well-known book, Majalis-ul-Mo'mineen (Note 1), Qazi Nurullah Shustari, a $16^{\text {th }}$ century historian, explicitly introduces all Kara Koyunlu leaders, especially Ispand, governor of Baghdad, as Shiites and speaks of Jahan Shah as "the Shiite Muslim." Nurullah Shustari describes the Kara Koyunlu as Shiites with certainty. In order to corroborate his claim, he cites the Shiite inscriptions on the rings worn by two of Kara Iskander Bey's (1420-1438 C.E) daughters and the inscriptions on the Mirza Pir Budak's ring, son of Jahan Shah (Majalis-ul-Mo'mineen, 1354, pp. 370; 582). As Shustari has explained, some Kara Koyunlu women have also been famous throughout history for their Shiism, including (in addition to Iskander Mirza's daughters) Jaan Begum Khatun, one of the well-known Khatuns of the Kara Koyunlu dynasty, who was Jahan Shah's wife. Some scholars refer to her as one of the few "Shiite female rulers" in Persian history. Jaan Begun Khatun was doubtlessly a Shiite. It was with her order that the Blue (Kabud) Mosque was constructed in Tabriz in 1465. This mosque is ornamented with the names of Imam Ali and his children (Turkmani Azar, 1385, pp. 331-332; 334). According to Shustari, because they were constantly occupied with fighting their enemies and opposers, the Kara Koyunlu never had the time to propagate Shia (Shustari, 1354, p. 367).

Mahmud Ibn Abdullah Ibn Neishaburi is another historian in whose book, This History of the Turkmen, states that the entire Kara Koyunlu family have had Shia faith and relates their numerous wars with Timur and his predecessors to this matter (Sumer, 1369, pp. 12-13).

Sakhavi, $15^{\text {th }}$ century historian, in his book Al-zoa-ul Lame', describes Jahan Shah's son, Pir Budak as an uncompromising Shiite (Sakhavi, 1412, p. 2).

Other sources that clearly refer to the Kara Koyunlu as Shiites are Tarikh-e Sultan Muhammad Qutb Shah (by an anonymous $17^{\text {th }}$ century writer) and Tarikh-e Asef Hajian by Khan Zaman Khan ( $19^{\text {th }}$ century historian). These sources mention explicitly that India's Qutb Shahs, who were descendants of the Kara Koyunlu, had had Shia religion before arriving in India (Tarikh-e Sulttan Muhammad Qutb Shah, 1st article; Khan Zaman Khan, 1377, p. 8). It has to be added that on the threshold of the decline of the Bahmani reign in 1512 C.E, the Qutb Shahi government was founded as one of the five successors of the Bahmani rule. Founder of this dynasty, Sultan Qoli Qutb Shah was the grandson of one of Jahan Shah's nephews who had immigrated to India (Roymer, 1380, p. 229). Regarding the Qutb Shahi dynasty, as it is noted in Tarikh-e Sultan Muhammad Qutb Shah, it is worth mentioning that Sultan Qoli had established Shia as the official religion of his territory before Shah Ismail declared Shia the official religion of Persia in 1501 (Tarikh-e Sultan Muhammad Qutb Shah, n.d., first article). This can be seen as a sign of the Kara Koyunlu descendants' rooted and determined belief in the Shia faith. In any case, we may induce from the sources of the Islamic history of India that the Shia beliefs of the founder of the Qutb Shahi dynasty- who proved his true faith in Shia with his actions, are a continuation of the Shia beliefs of the Kara Koyunlu and so be persuaded that the Kara Koyunlu had been Shiites. Furthermore, this fact meets another criterion for "being a Shiite", namely "familial connection or personal attachment to a one of the Shia-faith families (Ja'farian, 1388, p. 81).

(b) Narratives from which the Kara Koyunlu's Shiism may be induced

About the inscription of the phrase "Ali Vali-ullah" in an edifice (apparently in front of the Kabud Mosque) called "Dar-ul Ziafah", Hashri Tabrizi $\left(17^{\text {th }}\right.$ century scholar) relates that when informed that Shah Hussein Wali, one of the sheikhs and mystics of the Kara Koyunlu age, had proved Ali's Vilayet(Note 2) after debating with Sunnite religious scholars and had convinced them, Shah Jahan ordered "Ali Vali-ullah to be inscribed inside the edifice as a blessing (Hashri Tabrizi, 1381, p. 61).

Other historical narratives from which we can infer the Kara Koyunlu's Shiism are narratives about the conflicts between the Kara Koyunlu and the Musha'sha'iyān. This is one of the important incidents of the period of Kara Koyunlu rule. Kara Koyunlu Jahan Shah dispatched an army to disperse them, but soon he called the army back and dissuaded them from warring with Musha'sha'iyān (1356, p. 262). The fact that Jahan Shah sent his army commander to confront the clique and later on issued a retreating order indicates that since the Kara Koyunlu 
were Shiites and had religious affinities with the Mushashaiyān, the Kara Koyunlu leader had no interest in fighting with them (Mir Ja'fari, 1384, p. 257).

Other historical narratives show that due to the Kara Koyunlu's being Shiites, people of some Shia cities such as Qom and Saveh sought refuge with them at the time of the Timurid invasion. In the era of Kara Yusuf (1407-1420 C.E), founder of the Kara Koyunlu Empire, who was famed for his Shiite inclinations and his rule coincided with that of Timurid Shahrukh, the fame of the Kara Koyunlu's Shiism manifested itself in a political manner with the disobedience of the people of Tabriz and Saveh to the Timurid and submission to the Kara Koyunlu (Tehrani: 1356, p. 383). At the time of the Kara Koyunlu Jahan Shah (1435-1467 C.E), the Turkmen were so well known for their Shia inclinations and Shia conversions that when the Timurid Babur (1447-1457 C.E), pursuing his conquests, attacked Saveh and Qom, the people of Saveh and Qom who could not tolerate Babur's governors' oppression, sought refuge with the Turkmen (Hondemir, 1353, p. 46). Therefore, we may say that this family's Shiism at the time of Jahan Shah and Kara Yusuf manifested itself politically in the submission of the people of some Shia cities to the Kara Koyunlu (Turkmani Azar, 1383, p. 231).

Other historical narratives that may be evidence of the Kara Koyunlu being Shiites are those historical sources that cite the Kara Koyunlu's reluctance to dispute with the Safavids due to their ideological affinities. According to the reports of the historical sources, when the fame of the Safavid Junayd attracted many followers to Ardabil, Jahan Shah became jealous and asked Junayd in a letter to disperse his disciples and leave Ardabil. Thus, Junayd went to Diyarbakir and was welcomed by Uzun Hassan. When informed of Junayd's return to Ardabil, Jahan Shah decided to send him into exile again. As a result, Junayd set out for Trabzon and Cherkess (Hondemir, 1353 , p. 426). It is believed that Sheikh Junayd was the first among the Safavid clergymen to claim mundane title and power and this caused Jahan Shah's discomfort and misgivings. For Jahan Shah, a Shia follower himself, it was not expedient to confront with an army a clergyman who had Shia faith (Mir Ja'fari, 1384, p. 258). We may confirm this inference from the above historical narrative by stating that the Kara Koyunlu were so militarily powerful that they could thwart any Safavid military coup in Azerbaijan and by leaving Ardabil, the center of the Safavid movement, Junayd had implicitly confessed to this (Savory, 1386, p. 16). Therefore, their tolerant approach toward the Safavids in this period was not because of their weakness, but because of their common stance toward to Shia. On the other hand, Sheikh Ja'far, Junayd's uncle, being appointed custodian of the Sheikh Safi Mausoleum indicates that Jahan Shah's behavior toward the Safavids was only because of his "jealousy" (Hondemir, 1353, p. 426) toward the growing power of a rival Shiite and if Junayd had not taken steps to come to some kind of power, the Kara Koyunlu ruler would not have had any problems with him.

Other materials in historical sources which implicate that the Kara Koyunlu were Shiites are Shia names such as Yaar Ali, Pir Ali, Hassan Ali, and Shokr Ali of the Kara Koyunlu princes (Tehrani, 1356, pp. 359-358). Bosworth has also noted this (Bosworth, 1381, p. 253).

Another source from which we can induce the Kara Koyunlu were Shiites is the Kara Koyunlu Jahan Shah's divan. Only a cursory perusal of the poems will reveal Shia feelings and phrases (Mazzavi, 1363, p. 144).

Narrative discourse of the Sunni historical sources implicating the Kara Koyunlu's Shiism:

If one is familiar with the discourse of the Sunni historians, one can easily find that accusations such as "heretic," "infidel," "bad believer," "religious deviate, and "atheist" were commonly used against Shiites in general and Shiites governors in particular throughout different times. Minorsky emphasizes that Jahan Shah, the greatest Kara Koyunlu sultan, was a "terrible heretic" for the Sunnites. Building on Minorsky's statement, Roymer introduces Jahan Shah as a "Shiite heretic" and considers the Kara Koyunlu as precursors of the Safavids regarding differences in belief with the Sunnites (Roymer, 1380, pp. 228-229). Concerning those Sunni sources whose type of discourse contains references to the Kara Koyunlu's Shiism we should point to Fazlullah Ibn Ruzbahan Khonji ( $15^{\text {th }}$ century historian). As a supporter of the Sunnite Kara Koyunlu, he accuses the Kara Koyunlu of having connection with heresy (Khonji, 1379, p.21). Also in Zubdat at-tavārīkh, Hafiz-i Abru calls Kara Yusuf a religiously deviate person (Hafiz-i Abru, 1379, p. 73). From Hafiz-i Abru's writings we can clearly understand that the religious matters of Kara Yusuf's era have not been in Sunnites' way (Rezaei, 1385, p. 72) which can be sign of the Kara Koyunlu having been Shiites. It must be said that in some cases these accusation surpassed mere "heresy" condemnation and changed to accusations of "infidelity." For instance, when Mamluk sultan was preparing himself for war against the Kara Koyunlu emperor, it was proclaimed among the public that Kara Yusuf and his son Shah Muhammad, governor of Baghdad, were heretics. The Egyptian caliph and judges also declared war against Kara Yusuf (Sumer, 1369, p. 118). It is obvious that the Sunnite Muftis would not have declared the Kara Koyunlu heretics if they had been Sunnites; furthermore, historical sources demonstrate that the Sunni Muftis never hesitated in calling Shiite governments heretic. The fact that the Egyptian traditional 
Muftis' declaration of the Kara Koyunlu's heresy was because of the Muftis' strong religious prejudice has also been pointed out by some scholars including Sumer (Sumer, 1369, pp. 129-130). Another accusation -repeatedly made throughout history by the Sunnites against Shiites is the accusation of "infidelity; the word Abubakr Tehrani uses when talking about Pir Budak (Tehrani, 1356, p. 371). Dowlatshah-e Samarkandi has also called Jahan Shah a bad believer (Samarkandi, 1353, pp. 342-346). The "atheism" accusation is a recurrent accusation common among some Sunnite scholars against Shiites. Monajjem Bashi, Turk historian, and Ibn-e Toqri Berdi describe Jahan Shah as inclined to "infidelity" and "atheism" and disinclined to divine decrees (Monajjem Bashi, n. d., p. 150; Ibn-e Toqri Berdi, v. 6, pp. 457-473).

\subsubsection{The Explicit Admission of the Person Himself to Being a Shiite in A Statement (or An Incident):}

Another criterion for being recognized as a Shiite is when the person himself says something that implies his being a Shiite or explicitly shows it (Ja'farian, 1388, p. 84). In this regard, we can cite an important piece of evidence from the era of the Kara Koyunlu. This evidence is Kara Yusuf the Turkman's letter to Shahrukh Mirza. In this letter, Kara Yusuf expresses his desire to visit Mashed and in so doing chooses words that explicitly point to his Shia beliefs (Navaee, 1370, p. 169). Moreover, we should point out that Kara Yusuf is, in fact, considered founder of the Kara Koyunlu government (Mir Ja'fari, 1384, p. 240). Therefore, this letter signifies that the Kara Koyunlu were Shia believers right from the start.

\section{Being Buried in One of the Holy Shia Shrine}

Another criterion for recognizing someone as a Shiite is the person's burial in the vicinity of the tombs of the Shia Imams (Ja'farian, 1388, pp. 43-44) or their descendents. Historical sources mention that the tomb of the Kara Koyunlu Jahan Shah's mother is situated next to the tombs of two Shia Imams' descendents in Isfahan. These two Imam descendents are grandchildren of Imam Ja'far Sadeq, the sixth Imam of the Twelver Shiites (Honarfar, 1344, pp. 341-343; Kheradmand, 1347, p. 45).

\section{Imprinting the Chant "Ali Vali-ullah" on Coins}

Another indication of the Kara Koyunlu's Shiism is existence of coins with Shia formulations. Numismatic findings show that there are coins remaining from the time of Jahan Shah, Hassan Ali Mirza (1467-1468 C.E) (Torabi Tabatabae, 2535, pp. 14-19) and Ispand Mirza (Shushtari, 1354, p. 370) which contain Shia formulations. Of course, there are some coins from the Kara Koyunlu era which have Sunni formulations (Hassanzadeh, 1386, 51). It appears that the Kara Koyunlu's intention in minting coins with Sunni formulations has been either to avoid an overt Shia policy so as not to scatter their Sunnite supporters or the political exigency demanded that they be tolerant in this regard because of their Sunnite neighbors. This could be interpreted as, to use Sumer's words, the Kara Koyunlu's "obvious compromise" to survive "the dangerous politico-religious movements of the time." (Roymer, 1380, p. 230) We should also bear in mind that perhaps by minting coins with Sunni chants, the Kara Koyunlu were considering a union of economy and religion. Evidently, striking all Kara Koyunlu coins with Shia chants might have engendered problems in the Kara Koyunlu government's international, economic relations with the Sunnite governments of the region. In the meantime, some scholars have argued that the simultaneous using of Sunnite and Shiite chants in the Kara Koyunlu coins shows reconciliation between the two Shia and Sunni faiths because no side objected. According to these scholars, this fact indicates that the circumstances were in favor of the Shiites more than before (Turkmani Azar, 1385, p. 331).

\section{Architectural Works}

Another criterion for determining Shia is existence of material work(s) containing themes or references pointing to a family or person's Shiism. In this respect, the Kara Koyunlu have left behind some architectural works which explicitly demonstrate their having been Shiites. The most important remaining work is The Blue (Kabud) Mosque of Tabriz. It is the first ornamented temple not to have included the names of any Rashidun Caliphate and its walls and arches are decorated with the chant "Ali Vali-ullah" and names of Imam Hassan and Hussein (second and third Shiite Imams) (Torabi Tabatabae, 1349, p. 43). In fact, this monument was constructed by the order of Jan Begum, Jahan Shah's wife (Ibn-ul Karbalae, 1344, p. 43). This monument, in truth, belongs to the Shiites (Turkmani Azar, 1384, p. 34).

In addition, there are the two mausoleums of Imam descendents in the Imam's Gate (Darb-e Emam) Complex in Isfahan which was built in 1453 in the reign of the Kara Koyunlu Jahan Shah (Mir Ja'fari, 1384, p. 277). These two are the descendents of Imam Ja'far Sadeq, the sixth Shiite Imam. In the vicinity of these two descendants' tombs is the grave of Jahan Shah's mother. The building itself from the one hand and the burial of one of the members of the Kara Koyunlu family from the other hand can be seen as indication of the Shia beliefs of this 
family. The Imam's Gate Complex has received much attention by many architects and researchers because of its Kara Koyunlu artistic and architectural values (Honarfar, 1344, pp. 341-343; Kheradmand, 1374, p. 45).

Once the criteria for establishing person's belief in Shia are determined and they are applied to the Kara Koyunlu, it is ascertained that six out of the ten criteria, namely an author or historian's explicit emphasis on the person being a Shiite, burial in the vicinity of one of the Shia Holy Shrines. The explicit admission of the person himself to being a Shiite in a statement (or an incident), imprinting the chant "Ali Vali-ullah" on coins, familial connection, and architectural works are particularly true about the Kara Koyunlu. Obviously, in most cases, if any of the aforementioned criteria matches with a person or family, it can be regarded as evidence of that person or family's belief in Shia whereas in the case of the Kara Koyunlu, a set of reasons indicate their having been Shiites. Thus, in this stage, we may judge about the Kara Koyunlu's Shiism in a general way.

\section{The Kara Koyunlu's Type of Shia}

We can corroborate that the Kara Koyunlu were Shiites based on the mentioned criteria and comparing them with the Kara Koyunlu. However, this question is raised that what was the type of Shia in which the Kara Koyunlu believed? Were they, as some scholars have mentioned, Twelver Shiites or Exaggerating Shiites? In order to identify the Kara Koyunlu's type of religion, we have to explain the religious circumstances of Persia after the Mongol invasion for in this way we may not only be able to determine the type of Shia in which the Kara Koyunlu believed, but also to pinpoint the reasons for the researchers' various and sometimes contradictory opinions on the religion of the Kara Koyunlu. Three points are noteworthy in the analysis of the religious transformations of Iran after the Mongol invasion:

1. After the Mongol invasion, due to lack of a strong, central power, political disintegration of Iran (Daftari, 1389 , p. 222), decline of the Sunni from its ruling position and the Mongols' religious tolerance, the Shiites found a new opportunity to participate in political and ideological activities to the extent that they improved significantly in different scientific, political and military areas (Navaii \& Ghaffari Fard, 1386, p. 4). Therefore, the situation generally changed in favor of the activities of some movements, most of them Shia ones or influenced by Shia (Daftari, 1389, p. 222).

2. Another issue was Sufism. With the Mongol conquest of Persia, a new phenomenon is unveiled and that is the increasing tendency of the public to Sufism. Obviously, this phenomenon was the direct result of oppression and frequent carnage and pillage by Mongols and Iranians' inability to deal with it (Turkmani Azar, 1385, pp. 294-295). It is known that Sufism first emerged in the Sunni, but in the process of Sufism's influence on Shia during the thirteenth and fourteenth centuries (C.E), Sufism's theoretical foundations were gradually added to the Shia culture. What made Sufism influence Shia was the similarities between the two such as common leaders and models (Ja'farian, 1388, p. 761). Besides, some Sufis like Sheikh Najmuddin Akbari stood up against social injustice. Sheikh Najmuddin's crusade was a leap in his Sufic thought toward Shia as Shia invites its followers to fight against oppression (Turkmani Azar, 1385, pp. 294-295). Therefore, the increasing effect of Shia on Iranian Sufism, the Kobravieh School, has been so much that some assume that the gradual and invisible journey from Sunni to Shia first manifested in the Kobravieh sect (Farahani Monfared, 1388, pp. 33-34). In this manner, upon the arrival of the Mongols in Persia, Sufism came nearer to Shia. In this period, Sufism acted like a bridge between Sunni and Shia and due to many reasons pave the way for the promulgation of Shia (Nasr, 1974, p. 272). It was through this process that the Sufic sects developed in Persia after the Mongol invasion apparently remained faithful to Sunni after their establishment, but after some time, some of these Sufic sects officially declared that they were Shiites (Daftari, 1375, p. 525). That is why Henry Corbin maintains that Shia is, in actuality, Sufism and true Sufism is contrariwise nothing but Shia (Corbin, 1337, pp. 46-63). The permeation of Exaggerating and Radical thoughts among the Shiites in the following centuries is somehow associated with these developments (Ja'farian, 1388, p.763). In addition, during the fourteenth and fifteenth centuries (C.E), a kind of "laic Shia" was being propagated through such Sufic teachings; the Twelver Shiites or other Shia sects did not propagate this Shia, and these Sufic sects are its actual propagators; hence, Marshal Hodgson calls it "Sectarian Shia." Claude Cahen also refers this strange process as "Shi'ization of Sunni" thus distinguishing from Shia propagation by any certain Shia sects and schools (Daftari, 1389, p. 223). Some other scholars have called this phenomenon "Sufic Shia" (Ja'farian, 1388, p. 762). This orientation is observed both among the laymen and the elite. The lay people approached Shia through their affections for the Ahl al-Bayt through "Shia Sects" and the elites through creation of works in which Shia signs could be seen. We should also mention that the affinity between Shia and Sufism was not only theoretical. Religious and social movements which were inherently made of Sufic and Shia essence are a chain whose first ring is the Sarbedars and its last ring is the Musha'sha'iyān (Savory, 1936, p. 628) and the Kara Koyunlu are exactly in the middle of this chain. The developments of the mentioned process which ultimately made the grounds for the general acceptance of Shia in 
Iranian society had reached its pinnacle during the Kara Koyunlu reign. That is why that not only are we able to determine the type of Shia in which the Kara Koyunlu believed, but also we can explain the reasons for various and sometimes contradictory opinions about the religion of the Kara Koyunlu. To be precise, the type of Shia in which the Kara Koyunlu believed has to be known as "Sectarian Shia" or "Sufic Shia" which was prevalent among the Kara Koyunlu in the guise of Sufism (Rezaei, 1385, p. 70). It also justifies some sources' report of certain Kara Koyunlu leaders' popularity, such as Jahan Shah, among Sufis (Mir Ja'fari, 1384, pp. 262-263) (Ibn-e Karbalae, 1344 \& 1349, p. 524). Furthermore, this type of Shia fuses some elements from Sufic thinking, Twelver Shia, Exaggerating Shia and Sunni in the process of its formation (Ja'farian, 1388, pp. 760-766). Each of these elements has taken a different shape in the reigns of different Kara Koyunlu leaders; for example, the Sufic aspect of Shia has manifested in Jahan shah (Mir Ja'fari, 1384, pp. 262-263), its prejudicial aspect in Pir Budak (Sakhavi, 1412, p. 203; Mazavi, 1363, 65; Mohsen Amin, 1406, pp. 301-303) and its Twelver-Shia aspects in Ispand Mirza (Shustari, 1354, p. 367) and this has caused many scholars to judge the Kara Koyunlu's being Twelver-Imam or Exaggerating Shiites or Sunnites by considering various independent components of this type of Shia apart from the entirety of the constituents of Sufic Shia and observing its isolated components among different Kara Koyunlu leaders whereas by recognizing the Kara Koyunlu as "Sectarian Shiites", we can firstly reach a verdict about their Shiism and secondarily distinguish their type of Shiism from common Shia sects such as Twelver and Exaggerating, i.e. Sectarian or Sufic Shia which they have not inherited from common Shia sects, but it has come to them through a so-called "Shi'ization of Sunni" process.

3. The third factor in this process is the role of "Shafi'i Faith" in the "Sunni Shi' ization" process in Iran. Due to persistent presence of Shafi'i Faith in Azerbaijan and also due the closeness of the Shafi'i and the Shiites, particularly concerning the prophet's family (Ahl al-Bayt), this closeness and eventually transformation of Sunni to Shia has occurred in a slow and gradual manner. The closeness of Shafi'i faith and Shia is an issue Nurollah Shustari mentions and writes, "Shams-uddin Muhammad Ibn Yahya Lahiji Nurbakhsh invited his Hanafi-faith disciples to Shafi'i and then to Shia (Shustari, 1354, p. 153).

\section{Conclusion}

After determining the "criteria for being recognized a Shiite" and comparing them with the Kara Koyunlu, we reach the conclusion that among the criteria mentioned for proving a person or family's Shiism, some of the criteria including a historian or writer's explicit reference, burial in the vicinity of Imam descendants' tombs, the person's own admission to being a Shiite, imprinting Shia chants on coins and architectural works are particularly true for the Kara Koyunlu and thereby we can corroborate the fact that the Kara Koyunlu were, in general, Shiites. Nevertheless, due to the religious evolutions of Iran in the period after the Mongol that led to the development of a process referred to as Twelver Sunni and Shi'ization of the Sunnites, a special type of Shia, called Sectarian Shia or Sufic Shia, spread in Iran which was propagated by the Sufis. This type of Shia contains various elements from Exaggerating Shia, Sufic Shia, Twelver Shia and even some elements from the Sunni and the Kara Koyunlu were its heirs. This "Sectarian" or "Sufic" Shia should be considered a different type of Shia which has come into existence through "the application of Shia concepts to the Sunni" and has not followed its path through common Shia sects such as Twelver Shia and Exaggerating Shia. It is this fact that not only determines the type of religion the Kara Koyunlu had, but also explains the variegated opinions of scholars about the Kara Koyunlu's religion as every scholar has referenced to the constituents of "Sectarian or Sufic Shia" (such as Exaggerating, Sufic, Twelver, etc all of which can be more or less seen in Kara Koyunlu leaders) in isolation disregarding the entirety of the elements of this type of Shia, hence their variegated and sometimes contradictory opinions regarding the Kara Koyunlu's religion. Finally, the Kara Koyunlu's short-lived rule spanning the present location of Azerbaijan and the Arabic Iraq can be regarded as a positive point in the Shia history of Iran. Having had Shia inclinations and beliefs, they fostered a suitable environment for the reception of Shia in Azerbaijan and Tabriz and pave the way for the thriving and establishment of Shia Faith as the official religion of the Safavid government.

\section{References}

Afandi, A. (nd.). Sahayef-ul Akhbar. Central Library of Tehran University

Amin, S. M. (1406 A.H). In A. Hasan-ul (Ed.), A'yan-ul Shi'a. Beirut: Dar-ul Tar'arof Lel Matbu'at.

Anonymous. History of Sultan Muhammad Qutb Shah with the handwriting of Nizam Ibn Abdullah Shirazi. Transcript No. 3885. Malek National Library.

Bosworth, C. E. (1381). The New Islamic Dynasties: A chronological and Genealogical Manual. Tehran: Markaz-e Bazshenasi Eslam va Iran. 
Corbin, H. (1337). Three topics about the history of spirituality in Iran. Faculty of Literature Journal, 5, 46-63. Tehran.

Daftari, F. (1375). History and Beliefs of the Ismailis. Tehran: Foruzanfar Research \& Publication.

Daftari, F. (1389). In S. Zakeri (Ed.), Ismailis and Iran (Article Collection). Tehran: Foruzanfar Research \& Publication.

Eskandar, B. T. (1350). In I. Afshar, (Ed.), Tarikhe- Alam Aray-e Abbasi. Tehran: Amir Kabir.

Hafiz-i Abru. (1372). In S. K. Haj Seyyed Javadi (Ed.), Zubdat at-tavārīkh (Vol. 1 \& 2). Tehran: Nashr-e Ney.

Hashri Tabrizi, M. M. A. (Ed.) (1381). Roze At'ha. Tabriz: Sotoodeh.

Hassanzadeh, E. (1366). The Rule of Ak Koyunlu and Kara Koyunlu Turkmen in Iran. Tehran: SAMT.

Hendushah, M. Q. (1301 A.H). Golshan-e Ebrahimi/Tarikh-e Fereshte. Lithography.

Hinz, W. (1362). Formation of National Government In Iran. Tehran: Khawrazmi Publication Company.

Honarfar, L. (1344). Historical Treasury of Isfahan. Tehran: Safghafi Bookshop.

Hondemir. (1353). In M. D. Siaghi (Ed.), Tarikh Habib al-Siyar fi Akhbar-e Afrad-e Bashar (Vol. 2 \& 4). Tehran: Khayyam Bookshop.

Ibn-e Arabshah. (1356). Ajayeb-ul Maqdur fi Akhbar-e Teimur. Tehran: Book Translation \& Publication Agency.

Ja'farian, R. (1370). Religion and Politics in the Safavid Era. Qom.

Ja'farian, R. (1388). History of Shia in Iran from the Dawn to the Fall of the Safavids. Tehran: Nashr-e Elm.

Karbalae Tabrizi, H. (1344, 1349). Ruzatuljanan v jannatuljanan. Tehran, bongahe tarjome

Khan Zaman Khan, Q. H. (1377). In M. M. Tavassoli (Ed.), History of Asef Hajian/Golzar Asefi. Eslam Abad: Persian Research Center of Iran \& Pakistan.

Kheradmand, H. (1375). A study about the historical complex of Darb-e Emam in Isfahan. Farhang-e Esfahan (Vol. 2 \& 3).

Khonji, E. F. R. (1379). In M. Sharghi (Ed.), Tarikhe- Alam Aray-e Amini. Tehran: Khanevadeh Publications.

Mazzavi, M. (1363). Rise of the Safavids. Tehran: Gostareh Publication.

Mir Ja'fari, H. (1384). History of Political, Social, Economic and Cultural Developments in Iran during the Timurids and the Turkmen. Isfahan: Isfahan University; Tehran University; SAMT.

Mir, A. Q. R. D. I. N. D. (1309 A.H). In S. A. Shirazi (Ed.), Hadiqat-ul Aam. Heydar Abad Dakan.

Monshi Qazvini, B. (1378).In M. Bahram Nejad (Ed.), Javaher-ul Akhbar (Section on History of Iran from the Kara Koyunlu to 984 A.H). Tehran: Written Heritage Publication Center.

Mostofi Qazvini, H. A. (1364). In A. Navaee (Ed.), Selected History. Tehran: Amir Kabir.

Muhammad, H. (1925 C.E). Montakhab-ul Lobab dar Ahvale- Salatin-e Mamaleke Dakan, Gojarat and Khandish. Calcutta.

Nasr, H. (1974). Religion in the Safavid Persia. Iranian Studies, 2. http://dx.doi.org/10.1080/00210867408701466

Navaee, A. (1370). Iran's Historical Correspondences; from Timur to Shah Ismail. Tehran: Scientific \& Cultural Publication Company.

Rezaee, M. (1385). History of Shia in Azerbaijan. Qom: Shialogy Publications.

Roymer, H. R. (1380). History of Persia (1350-1750). Tehran: Tehran University.

Sakhavi, S. M. A. (1992). Al-lame lel Ahl-el Qeran-el Tase'. Beirut: Dar-ul Jalil.

Samarkandi, K. A. (1353). Matla'us Sa'dain. Tehran: Tahuri.

Savory, R. (1936). Religion in the Timurid and Safavid Period. In P. Jackson, \& L. Lockhart (Eds.), The Cambridge History of Iran (Vol. 6). Cambridge University Press.

Savory, R. M. (1387). Iran Under the Safavids. Tehra: Markaz Publication.

Shushtari, S. N. (1354). Majalis-ul-Mo'mineen. Tehran: Islamyieh Bookshop. 
Sumer, F. (1369). The Kara Koyunlu. Tehran: Cultural Studies Institute.

Tehrani. A. (1356). In Nejati Oqal \& F. Sumer (Eds.), Diare Bokryieh (Vol. 2).Tehran: Tahuri.

The Organization for Researching and Composing University textbooks in the Humanities. (1385). In S. A. R. Khezri (Ed.), History of Shia . Qom: Hawzah \& University Research Center.

Torabi Tabatabaei, S. J. (1349). Engravings and Ornamentations in Kabud Mosque of Tabriz. Tabriz.

Torabi, T. (2535). seyyed jamal, Ak Koyunlu coins and the basis for the unity of Safavid government in Iran. Azerbaijan Museum Journal, 7.

Turkmani Azar, P. (1383). Political History of Twelver Shiites in Iran. Qom: Shialogy Institute.

Valeh Esfahani, M. Y. (1379). In M. H. Mohaddes (Ed.), Khold-e Barin (Sixth \& Seventh Rowzeh; history of Timurids and Turkmen). Tehran: Written Heritage. 